J. Dairy Sci. 95:1527-1544

http://dx.doi.org/10.3168/jds.2011-4410

(C) American Dairy Science Association ${ }^{\circledR}, 2012$.

\title{
Food intake, milk production, and tissue changes of Holstein-Friesian and Jersey $\times$ Holstein-Friesian dairy cows within a medium-input grazing system and a high-input total confinement system
}

\author{
E. R. Vance, ${ }^{\star} †$ C. P. Ferris, ${ }^{\star 1}$ C. T. Elliott, † S. A. McGettrick, $\neq$ and D. J. Kilpatrick§ \\ ${ }^{*}$ Agri-Food and Biosciences Institute, Large Park, Hillsborough, Co. Down, BT26 6DR, United Kingdom \\ †Agri-Food and Land Use, School of Biological Sciences, Queen's University Belfast, Belfast, BT9 5AY, United Kingdom \\ $¥$ Agri-Food and Biosciences Institute, Veterinary Sciences Division, Stoney Road, Belfast, BT4 3SD, United Kingdom \\ $\S$ Agri-Food and Biosciences Institute, Newforge Lane, Belfast, BT9 5PX, United Kingdom
}

\section{ABSTRACT}

Although interest in crossbreeding within dairy systems has increased, the role of Jersey crossbred cows within high concentrate input systems has received little attention. This experiment was designed to examine the performance of Holstein-Friesian (HF) and Jersey $\times$ Holstein-Friesian $(\mathrm{J} \times \mathrm{HF})$ cows within a high concentrate input total confinement system $(\mathrm{CON})$ and a medium concentrate input grazing system (GRZ). Eighty spring-calving dairy cows were used in a 2 (cow genotype $) \times 2$ (milk production system) factorial design experiment. The experiment commenced when cows calved and encompassed a full lactation. With GRZ, cows were offered diets containing grass silage and concentrates [70:30 dry matter (DM) ratio] until turnout, grazed grass plus $1.0 \mathrm{~kg}$ of concentrate/day during a 199-d grazing period, and grass silage and concentrates (75:25 DM ratio) following rehousing and until dryingoff. With CON, cows were confined throughout the lactation and offered diets containing grass silage and concentrates (DM ratio; 40:60, 50:50, 40:40, and 75:25 during d 1 to 100, 101 to 200, 201 to 250 , and 251 until drying-off, respectively). Full-lactation concentrate DM intakes were 791 and $2,905 \mathrm{~kg} / \mathrm{cow}$ for systems GRZ and CON, respectively. Although HF cows had a higher lactation milk yield than $\mathrm{J} \times \mathrm{HF}$ cows, the latter produced milk with a higher fat and protein content, so that solids-corrected milk yield (SCM) was unaffected by genotype. Somatic cell score was higher with the $\mathrm{J} \times \mathrm{HF}$ cows. Throughout lactation, HF cows were on average $37 \mathrm{~kg}$ heavier than $\mathrm{J} \times \mathrm{HF}$ cows, whereas the $\mathrm{J} \times \mathrm{HF}$ cows had a higher body condition score. Within each system, food intake did not differ between genotypes, whereas full-lactation yields of milk, fat plus protein, and SCM were higher with CON than with

Received March 31, 2011.

Accepted November 1, 2011.

${ }^{1}$ Corresponding author: conrad.ferris@afbini.gov.uk
GRZ. A significant genotype $\times$ environment interaction was observed for milk yield, and a trend was found for an interaction with SCM. Crossbred cows on CON gained more body condition than HF cows, and overall pregnancy rate was unaffected by either genotype or management system. In summary, milk and SCM yields were higher with CON than with GRZ, whereas genotype had no effect on SCM. However, HF cows exhibited a greater milk yield response and a trend toward a greater SCM yield response with increasing concentrate levels compared with the crossbred cows.

Key words: crossbreeding, genotype $\times$ environment interaction, milk production

\section{INTRODUCTION}

The Holstein-Friesian is the dominant dairy cow breed within many countries, a reflection of the high genetic potential of the breed for milk production. However, selection for milk production within the Holstein-Friesian breed has led to a decline in functional traits and this has prompted a renewed interest in crossbreeding. Although many breeds have been used within crossbreeding programs, there is particular interest in the Jersey breed because of its ability to improve milk composition. Indeed, although many studies have reported higher milk yields with Holstein-Friesian cows than with Jersey crossbred cows, differences in milk solids yields tend to be much smaller or nonexistent, especially when these 2 genotypes are compared within lower concentrate input grazing systems (Auldist et al., 2007; Prendiville et al., 2009). The ability of smaller Jersey crossbred cows to compete with larger Holstein cows in terms of milk solids production appears not to be driven by differences in tissue mobilization or deposition between genotypes, but by the higher intake capacity per unit of BW of crossbred cows (Prendiville et al., 2009). In addition, clear evidence exists of improved health, fertility, and longevity with Jersey crossbred cows compared with purebred Holstein cows 
(Harris et al., 2000; Auldist et al., 2007), while there is some evidence of differences in the fatty acid content of milk produced by these 2 genotypes (Palladino et al., 2010).

Nevertheless, crossbred cows have traditionally been perceived to be primarily suited to lower concentrate input systems. However, in a recent study, HolsteinFriesian and Jersey $\times$ Holstein-Friesian cows were compared within 3 grassland-based systems of milk production involving concentrate inputs of approximately 0.5 , 1.1, and $1.7 \mathrm{t} /$ cow per lactation (Vance, 2011). Across the range of concentrate inputs examined within that experiment, no evidence was found of a genotype $\times$ nutrition interaction for any of the parameters examined, with both genotypes exhibiting similar milk production responses to the increasing levels of concentrates offered. Although the findings of that study suggest that Jersey crossbred cows may have a role in higher input systems, the highest concentrate input examined within this study would still be considered "moderate input" within many countries where confinement systems are practiced. Although Heins et al. (2006) examined the performance of Normande $\times$ Holstein, Scandinavian Red $\times$ Holstein, and Montbeliarde $\times$ Holstein cows within high concentrate input systems, studies examining the performance of Jersey $\times$ Holstein crossbred cows within these systems are limited. In one notable exception, Holstein cows and Jersey $x$ Holstein crossbred cows were offered a TMR containing approximately $50 \%$ forage on a DM basis from d 4 until d 150 of lactation (Heins et al., 2008a). Holstein cows produced a greater volume of milk than the crossbred cows, but neither DMI nor fat plus protein yield was affected by genotype. In addition, although evidence of a genotype $\times$ nutrition interaction has been identified in experiments comparing different strains (Horan et al., 2005) of Holstein-Friesian cows and different breeds of cows (Keady and Mayne, 2002), to date no evidence has been found of a genotype $\times$ nutrition interaction in studies involving comparisons of purebred and crossbred cows.

Thus, the objective of this study was to compare milk production performance, milk fatty acid content, changes in body tissue reserves, and fertility performance of Holstein-Friesian $(\mathbf{H F})$ and Jersey $\times$ Holstein-Friesian $(\mathbf{J} \times \mathbf{H F})$ cows within a high concentrate input total confinement system and a medium concentrate input grazing system.

\section{MATERIALS AND METHODS}

This study was conducted at the Agri-Food and Biosciences Institute (AFBI, Hillsborough, N. Ireland) between January 2009 and February 2010. Four treat- ments were examined in a continuous 2 (cow genotype) $\times 2$ (milk production system) factorial design experiment. The experiment commenced when the cows calved and was conducted over a full lactation.

\section{Animals}

The experiment involved 80 spring-calving dairy cows, $40 \mathrm{HF}$ and $40 \mathrm{~J} \times \mathrm{HF}$ cows. The HF cows had a mean PTA (PTA $\left.{ }_{2010}\right)$ for fat plus protein yield of +13.9 $\mathrm{kg}$ and a mean Profitable Lifetime Index $\left(\mathbf{P L I}_{2010}\right)$ of $+£ 47$, with these cows being within the top $10 \%$ of Holstein-Friesian cows in the UK for these 2 parameters. The HF cows used in the experiment were sired by 19 Holstein-Friesian sires. The $\mathrm{J} \times \mathrm{HF}$ cows were the offspring of a breeding program in which randomly selected Holstein-Friesian cows from the AFBI Hillsborough herd were bred to Jersey sires $(\mathrm{n}=9)$ of Danish ( $\mathrm{n}=16$ cows) and New Zealand $(\mathrm{n}=24$ cows $)$ origin, with the Jersey sires having a weighted $\mathrm{PTA}_{2010}$ for fat plus protein yield of $+21.0 \mathrm{~kg}$ and a weighted $\mathrm{PLI}_{2010}$ of $+£ 118$. The dams of HF and $\mathrm{J} \times \mathrm{HF}$ cows in this experiment had similar genetic potentials, having mean $\mathrm{PTA}_{2010}$ for fat plus protein yield of +9.7 and $+6.8 \mathrm{~kg}$, respectively, and mean $\mathrm{PLI}_{2010}$ of $+£ 24$ and $+£ 23$, respectively. All genetic parameters presented above were determined within the April 2011 proof run. Within each genotype, 10 cows were primiparous and the remaining 30 cows were multiparous, with the HF and $\mathrm{J} \times \mathrm{HF}$ cows having a mean lactation numbers of 2.4 and 2.3 , respectively.

\section{Treatments}

Within genotype, cows were allocated within $36 \mathrm{~h}$ of calving to 1 of 2 milk production systems: a total confinement system $(\mathbf{C O N})$ and a moderate input grazing system (GRZ). Within each genotype, cows were balanced across the 2 milk production systems according to calving date, parity, precalving BW and BCS, sire, PTA for fat + protein yield, and PLI (HF cows), and dam genetic potential for PLI and fat plus protein yield $(\mathrm{J} \times \mathrm{HF}$ cows $)$. Full details of each of the 2 systems are described below. Cows on treatments $\mathrm{CON}$ ( $\mathrm{HF}$ and $\mathrm{J}$ $\times \mathrm{HF})$ and GRZ ( $\mathrm{HF}$ and $\mathrm{J} \times \mathrm{HF}$ ) had mean calving dates of February 6, 8, 2, and 9, respectively.

Total Confinement System. Cows on this system were confined in cubicle accommodation throughout the experiment and offered a diet consisting of grass silage and concentrates. Cubicles were fitted with rubber mats that were cleaned daily, bedded with sawdust thrice weekly, and treated with lime weekly. Concrete passageways within the house were scraped a minimum of 6 times daily using an automatic scraper system. 
The forage:concentrate ratio of the diet (DM basis) was as follows: 40:60 from calving until the 2 genotype groups were a mean of 100 DIM, 50:50 until a mean of 200 DIM, and 60:40 until a mean of 250 DIM. Although we planned that the latter concentrate feed level would be maintained until the end of lactation, excessive BCS gain by the $\mathrm{J} \times \mathrm{HF}$ cows in late lactation (mean BCS of 2.9 at $d 240$ of lactation) necessitated increasing the forage:concentrate ratio to 75:25 from d 250 of lactation onward. Cows remained on the latter diet until they were dried off, with $\mathrm{HF}$ and $\mathrm{J} \times \mathrm{HF}$ cows on $\mathrm{CON}$ completing a mean of 325 and 303 DIM, respectively. Grass silages offered were produced from primary growth, primary regrowth and secondary regrowth herbage (mean harvest dates of May 21, July 10, and September 28, respectively) harvested from predominantly perennial ryegrass (Lolium perenne) based swards. Herbage was harvested using a self-propelled precision chop forage harvester and ensiled in pit silos. The silages produced from primary growth, primary regrowth, and secondary regrowth herbages were offered for proportionally 0.40 (calving until July 3), 0.35 (July 4 to November 8), and 0.25 (November 9 to the end of the dry period) of the total cow feeding days within the experiment, respectively, with these representing the proportional yields for first, second, and third harvests within a "3-cut" grass silage system (Mayne and Gordon, 1986). The ingredient composition of the concentrate offered $(\mathrm{kg} / \mathrm{t}$, air-dry basis) from calving until drying-off was as follows: barley, 150; maize meal, 150; sugar beet pulp, 150; citrus pulp, 150; soybean meal, 260; rapeseed meal, 80; Megalac (Volac Ltd., Orwell, UK), 20; calcined magnesite, 5; Molaferm (United Molasses, Belfast, UK), 10, and minerals and vitamins, 25 . In addition, $0.5 \mathrm{~kg} / \mathrm{cow}$ of the same concentrate was offered in the parlor during each milking.

Cows accessed their feed via a Calan gate feeding system (American Calan, Northwood, NH), with each Calan gate linked to an automatic cow identification system, allowing cows to gain access to feed boxes mounted on weigh scales (Griffith Elder, Bury St. Edmunds, UK). This system allowed individual cow food intakes to be recorded. Each day, uneaten food was removed from the feed boxes at approximately 0830 $\mathrm{h}$ and replaced with fresh feed (offered ad libitum at proportionally 1.1 of the previous days intake) between 0930 and $1000 \mathrm{~h}$. Between calving and 250 DIM, genotype groups were penned separately, with each group having access to 7 Calan gates. Thereafter, it was necessary to combine the 2 genotypes into a single group; however, each genotype continued to access food through separate Calan gates.

Medium-Input Grazing System. From calving until the commencement of grazing, cows on system
GRZ were housed in the same cubicle accommodations as described for $\mathrm{CON}$ and offered a complete diet (through the same Calan gate feeding system described for $\mathrm{CON}$ ) with a forage:concentrate ratio (DM basis) of 70:30. The grass silage (primary growth) and concentrates offered were as described for the early lactation period with system CON. These cows were also offered $0.5 \mathrm{~kg}$ of the same concentrate in the parlor during each milking.

Cows commenced grazing on March 9, with full-time turnout occurring on April 2. Following commencement of grazing, the duration of the daily grazing period increased from approximately 2 to $6 \mathrm{~h} / \mathrm{d}$ (milking to milking) by March 18, and to $9 \mathrm{~h} / \mathrm{d}$ between March 19 and April 1. On April 1, winter concentrates offered in the complete diet were withdrawn and replaced with $4.0 \mathrm{~kg} /$ cow per day of a grazing concentrate, with concentrate feed levels gradually reduced to $1.0 \mathrm{~kg} / \mathrm{cow}$ per day by April 24, with this divided between 2 equal feeds (offered during morning and evening milkings). The ingredient composition of the grazing concentrate offered (kg/t, air-dry basis) was as follows: barley, 190; maize, 190; sugar beet pulp, 310; soybean meal, 200; rapeseed meal, 40; calcined magnesite, 10; Molaferm, 30 ; and minerals and vitamins, 30 .

Throughout the grazing season a rotational paddock grazing system was adopted, with the core grazing area comprising 21 one-day paddocks ( 0.21 ha each) for each genotype. Paddocks for each genotype were arranged side by side across the grazing area, with additional grazing paddocks introduced into the rotation as the season progressed. Paddocks that were not grazed during a rotation (due to excess grass being available, as determined by a "grass wedge" grassland management tool) were either grazed by a group of nonexperimental cows or cut and baled for silage.

From the start of turnout until March 25, cows grazed part paddocks, with fresh herbage being allocated to cows daily (according to the number of cows in the group and herbage mass), to achieve a target residual sward height of $55 \mathrm{~mm}$. Thereafter, cows were offered whole paddocks during each 24 -h period for the remainder of the grazing season. During the early grazing period (from full-time turnout until April 24), paddocks were dusted with calcined magnesite $(210 \mathrm{~g} / \mathrm{cow}$ per day) daily to ensure cows had an adequate intake of magnesium. Adverse weather conditions during a 9-d period during rotation 1 , and during a 48 -h period in each of rotations 2 and 3, necessitated cows being rehoused and offered grass silage ad libitum. Seven grazing rotations were completed during the grazing season, with these lasting $27,21,18,18,20,24$, and 30 $\mathrm{d}$, respectively. The mean grazing season stocking rate for both genotype groups was 4.4 cows/ha. 
Throughout the grazing season, pre- and postgrazing sward heights were measured daily within the grazing area for each genotype (40 measurements in a "W" formation) using a rising plate meter (Jenquip, Feilding, New Zealand). During the course of the grazing season, mean pre- and postgrazing sward heights were 8.8 (SD 1.96) and 4.8 (SD 1.17) $\mathrm{cm}$, respectively, for the $\mathrm{HF}$ cows, and 8.6 (SD 1.92) and 4.8 (SD 1.26) cm, respectively, for the $\mathrm{J} \times \mathrm{HF}$ cows. These pregrazing sward heights represent pregrazing herbage masses of 3,100 and $3,030 \mathrm{~kg}$ of DM/ha (measured above ground level) for the $\mathrm{HF}$ and $\mathrm{J} \times \mathrm{HF}$ cows, respectively (determined using the herbage mass equation described later).

Fertilizer $\mathrm{N}$ in the form of urea (proportionally 0.46 $\mathrm{N})$ was applied to the entire grazing area at a rate of $25 \mathrm{~kg}$ of N/ha on February 17. Thereafter, fertilizer in the form of calcium ammonium nitrate (proportionally $0.27 \mathrm{~N}$ ) was applied to paddocks at a rate of 45, 30,30, $30,25,25$, and $20 \mathrm{~kg}$ of $\mathrm{N} /$ ha during each of grazing cycles 1 to 7, respectively. On a few occasions during the grazing season, when grass growth rates were high, fertilizer was not applied to individual paddocks with high residual herbage covers. Over the entire grazing season, the total fertilizer $\mathrm{N}$ application rate on the 21 core grazing paddocks was $240 \mathrm{~kg}$ of $\mathrm{N} / \mathrm{ha}$. The entire grazing area was trimmed (topped) to approximately $50 \mathrm{~mm}$ midway through the grazing season.

Daily concentrate feed levels remained at $1.0 \mathrm{~kg} / \mathrm{cow}$ per day until September 17, and then, as a consequence of grass shortages, were increased to $2.0 \mathrm{~kg} /$ cow per day until rehousing. Cows continued full-time grazing until October 18 (199 d), after which they grazed by day and were housed by night until October 23. Fulltime rehousing took place on October 23. Following rehousing, cows were offered a complete diet with a forage:concentrate ratio (DM basis) of $75: 25$, as described previously for CON. At this stage, the 2 GRZ genotype groups were combined into a single group, with each genotype having access to separate Calan gates. Both HF and $\mathrm{J} \times \mathrm{HF}$ cows on GRZ completed a mean of 291 and 302 DIM, respectively.

\section{Breeding and Dry Period Management}

Breeding commenced on April 1 and finished on June 24 , with all cows having a minimum voluntary waiting period before breeding of $42 \mathrm{~d}$. Throughout the breeding season cows were bred using AI. Pregnancy was confirmed via rectal scanning at d 60 post-AI. Cows with a BCS of $\geq 2.5$ were dried off either 8 wk precalving or when average weekly milk yields fell below 5.0 $\mathrm{kg} / \mathrm{d}$, whereas cows with a BCS of 2.25 or $\leq 2.0$ were dried off at either 10 or $12 \mathrm{wk}$ precalving, respectively. After being dried off, cows were removed from their genotype group and housed as a single group in cubicle accommodation, as described earlier. Cows within each treatment that were not pregnant remained on their treatment diet for the same mean number of days as pregnant cows within that treatment, after which they were removed from the experiment.

\section{Measurements}

Cows were milked twice daily, between 0600 and 0800 $\mathrm{h}$, and between 1500 and $1700 \mathrm{~h}$, with milk yields recorded automatically at each milking. Milk fat, protein, and lactose concentrations were determined weekly using 2 consecutive (a.m. and p.m.) milk samples (Milkoscan, model FT 120, Foss UK Ltd., Warrington, UK), and milk SCC was determined monthly using a Fossomatic 360 (Foss Electric, Hillerød, Denmark). In addition, on 3 occasions when cows on GRZ were grazing full-time (April 27, July 27, and October 5) milk was sampled from all cows during 2 consecutive milkings (a.m. and p.m.), bulked in proportion to yield, and subsequently analyzed for milk fatty acid concentrations as described by Keady et al. (2000). In addition, milk progesterone concentrations were determined twice weekly (Tuesday and Friday; a.m. milk samples) between calving and d 70 postcalving. Milk samples were preserved (Lactab Mark III, Thompson and Cooper Ltd., Lydney, UK) and stored at $4^{\circ} \mathrm{C}$ until analyzed (within 4 wk). Milk progesterone concentrations were determined using an ELISA kit (Ridgeway Science Ltd., Lydney, UK) based on the method of Sauer et al. (1986). Commencement of luteal activity was defined as the interval from calving to the first of at least 2 consecutive progesterone concentrations of $\geq 3 \mathrm{ng} / \mathrm{mL}$.

Cow BW was recorded automatically after each milking and an average BW calculated for each week. Body condition score was assessed weekly by 2 trained operators on alternate weeks using a 5-point scale (Edmonson et al., 1989), where $1=$ emaciated and $5=$ extremely fat. Blood samples were taken from the coccygeal vein of each cow between 0600 and $0730 \mathrm{~h}$, at wk 2, 4, 6, 10 ( $\pm 3 \mathrm{~d}), 20,30$, and 40 ( $\pm 7 \mathrm{~d}$ ) postcalving. Blood plasma was recovered via centrifugation and stored at $-20^{\circ} \mathrm{C}$ until analyzed for concentrations of NEFA (using a Wako kit, Wako Chemicals GmbH, Neuss, Germany) and glucose (using an Olympus kit, Olympus Life and Material Science Europa, Munich, Germany) using a Chemistry Immuno Analyzer (Olympus AU640).

In addition to the daily measurements of pre- and postgrazing herbage heights described earlier, on one occasion approximately every 10 to $12 \mathrm{~d}, 10$ locations were selected across the grazing areas (representing a range of herbage heights, from immediate postgrazing to immediately pregrazing) and herbage height mea- 
sured within a $0.36 \mathrm{~m}^{2}$ quadrat $(60 \mathrm{~cm} \times 60 \mathrm{~cm})$ using a rising plate meter (4 "drops" per quadrat). Herbage within each quadrat was subsequently cut to ground level using battery operated hand shearers (Gardina Accu 6; Kress and Kastner, Weiterstadt, Germany), the weight of herbage recorded, and the DM content of the herbage determined. Herbage DM yield within each quadrat was subsequently determined. At the end of the grazing season, mean grass height $(\mathrm{cm})$ and the associated herbage mass ( $\mathrm{kg}$ of $\mathrm{DM} / \mathrm{ha}$ ) within each quadrat were used to develop a linear relationship relating herbage height $(\mathrm{cm})$ to herbage mass, as follows:

$$
\text { Herbage mass }=(\text { herbage height } \times 341.1)+94.7 .
$$

This equation was then used retrospectively to determine pre- and postgrazing herbage mass within each paddock on a daily basis (based on daily pre- and postgrazing sward heights), with the herbage intake of each genotype group calculated as the difference between these 2 values. A mean herbage intake was then calculated for the entire grazing season for each genotype group.

\section{Feed Analysis}

Grass silage offered was sampled daily and analyzed for oven DM, while a fresh silage sample was analyzed twice weekly for gross energy, $\mathrm{N}, \mathrm{pH}$, ammonia-N, and volatile components. Dried samples were retained weekly, bulked for each 4-wk period, and subsequently analyzed for ADF, NDF, and ash concentrations. During the grazing season, herbage pluck samples were taken within each grazing area once weekly, with the samples bulked for each 4-wk period. Samples were analyzed for oven DM, ADF, NDF, N, gross energy, water-soluble carbohydrate, and ash concentrations. In addition, a fresh sample of grass was analyzed each week for ME content using near infrared reflectance spectroscopy as described by Park et al. (1998) for grass silage, but using a calibration equation developed for fresh grass. Each 1-t batch of concentrates produced during the study was sampled, with samples bulked for each 4-wk period. Bulked samples were analyzed for oven DM, N, ADF, NDF, GE, and ash. The feedstuffs offered were analyzed as described by Ferris et al. (1999), except for the GE content of silage, which was determined on a fresh sample, as described by Porter (1992).

\section{Statistical Analysis}

Data from $3 \mathrm{HF}$ cows (one from $\mathrm{CON}$ and 2 from GRZ) were excluded from the analysis (2 due to gen- eral poor health and one due to repeated mastitis), and data from $2 \mathrm{~J} \times \mathrm{HF}$ cows were excluded due to a problem of cross-suckling. Data was analyzed using GenStat Version 11.1 (Payne et al., 2008). The experiment was analyzed as a 2 (cow genotypes) $\times 2$ (milk production systems) factorial design experiment, with excluded cows replaced by missing plots. Data describing milk output, BW and BCS, and reproductive performance (continuous data) were analyzed using ANOVA, whereas binomial data were analyzed using logistic regression analysis. Data describing full lactation milk yield, milk composition, milk solids yield, and SCM were adjusted using DIM as a covariate, thus bringing all data to a common lactation length basis, namely 305 d. Similarly, DIM was used as a covariate when analyzing mean BW and mean BCS data. The effect of genotype on food intake was analyzed separately for cows managed on systems CON and GRZ using ANOVA. The effect of genotype and milk production system on milk fatty acid content was analyzed using repeated-measures REML analysis according to the $2 \times 2$ factorial design. In addition, weekly BW and BCS data, and blood metabolite concentrations at each sampling period was analyzed using repeated-measures REML analysis with the model including the fixed effects of genotype, system, and time. The effect of cow genotype and management system on the shape of the lactation curves for milk yield and fat plus protein yield was determined by fitting an exponential model curve (Wilmink, 1987):

$$
\mathrm{Yt}=a+b \times \mathrm{e}^{-0.05 \times \mathrm{t}}+c \times \mathrm{t} .
$$

Within this model $a, b$, and $c$ parameters relate to the intercept, the incline, and the decline of the curve, respectively, and Yt relates to milk production on day t. The effect of treatment on each of the coefficients ( $a$, $b$, and $c$ ) was examined using ANOVA according to a 2 $\times 2$ factorial design of the experiment. Peak yield and days to peak yield were derived for each individual cow, and tested for significance as described above.

\section{RESULTS}

The grass silages offered during this experiment were variable in composition, with $\mathrm{DM}$ and $\mathrm{CP}$ concentrations ranging from 229 to $382 \mathrm{~g} / \mathrm{kg}$, and 123 to $151 \mathrm{~g} /$ $\mathrm{kg}$ of DM, respectively (Table 1). However, all silages were well preserved as indicated by their low ammonia$\mathrm{N}$ and high lactate concentrations. Concentrates offered during the confinement and grazing periods had mean CP concentrations of 204 and $180 \mathrm{~g} / \mathrm{kg}$ of DM, respectively. The herbage grazed by each of the 2 genotypes 
was similar for each of the composition parameters presented in Table 1.

\section{Food Intake}

Dry matter intake did not differ significantly between genotypes during any of the key management phases with CON (Table 2). Similarly, with GRZ, genotype had no effect on DMI either during the period between calving and turnout or during the period between fulltime housing and the end of lactation. Total DMI during the lactation were 5,813 and $5,559 \mathrm{~kg}$ for the $\mathrm{HF}$ and $\mathrm{J} \times \mathrm{HF}$ cows, respectively $(\mathrm{CON})$, and 4,668 and $4,750 \mathrm{~kg}$ for the $\mathrm{HF}$ and $\mathrm{J} \times \mathrm{HF}$ cows, respectively (GRZ).

\section{Milk Production}

Although full-lactation milk yield was highest with the HF cows $(P<0.01), \mathrm{J} \times \mathrm{HF}$ cows produced milk with higher fat and protein concentrations $(P<0.001$; Table 3$)$. The overall effect was that genotype had no significant effect on SCM, fat yield, protein yield, or fat plus protein yield. Although genotype had no effect on the proportion of cows with one or more cases of mastitis, J $\times$ HF cows had a higher SCS than the HF cows. Production system had no effect on either milk fat or milk protein concentration, whereas milk yield, $\mathrm{SCM}$, and fat + protein yield were higher with CON $(P$ $<0.001)$. A significant genotype $\times$ system interaction was observed for milk yield $(P<0.05)$, and a trend was observed for a significant interaction for SCM $(P$ $=0.069)$.

Holstein-Friesian cows produced milk with higher concentrations of C14:1, C16:1, and C18:1 fatty acids $(P<0.05, P<0.001$, and $P<0.05$, respectively $)$ and with a higher conjugated linoleic acid (CLA) content $(P<0.01)$ than the $\mathrm{J} \times \mathrm{HF}$ cows, whereas the $\mathrm{J} \times$ HF produced milk with a higher C18:0 concentration $(P<0.001$; Table 3). Concentrations of short-chain fatty acids (C4-C14) and C16:0 were unaffected by genotype. Cows on CON produced milk with higher concentrations of $\mathrm{C} 4-\mathrm{C} 14(P<0.05), \mathrm{C} 16: 0, \mathrm{C} 18: 2(P$ $<0.001)$, and $\mathrm{C} 20: 0(P<0.01)$ fatty acids, and lower concentrations of C18:0, C18:1, and C18:3 $(P<0.001)$ fatty acids. Cows on system GRZ produced milk with a higher CLA content than those on system CON ( $P$ $<0.001)$.

\section{Lactation Profiles}

Parameters of the Wilmink curve $(a, b$, and $c)$ that describe lactation profiles for daily milk yield and daily fat plus protein yield for the $\mathrm{HF}$ and $\mathrm{J} \times \mathrm{HF}$ cows

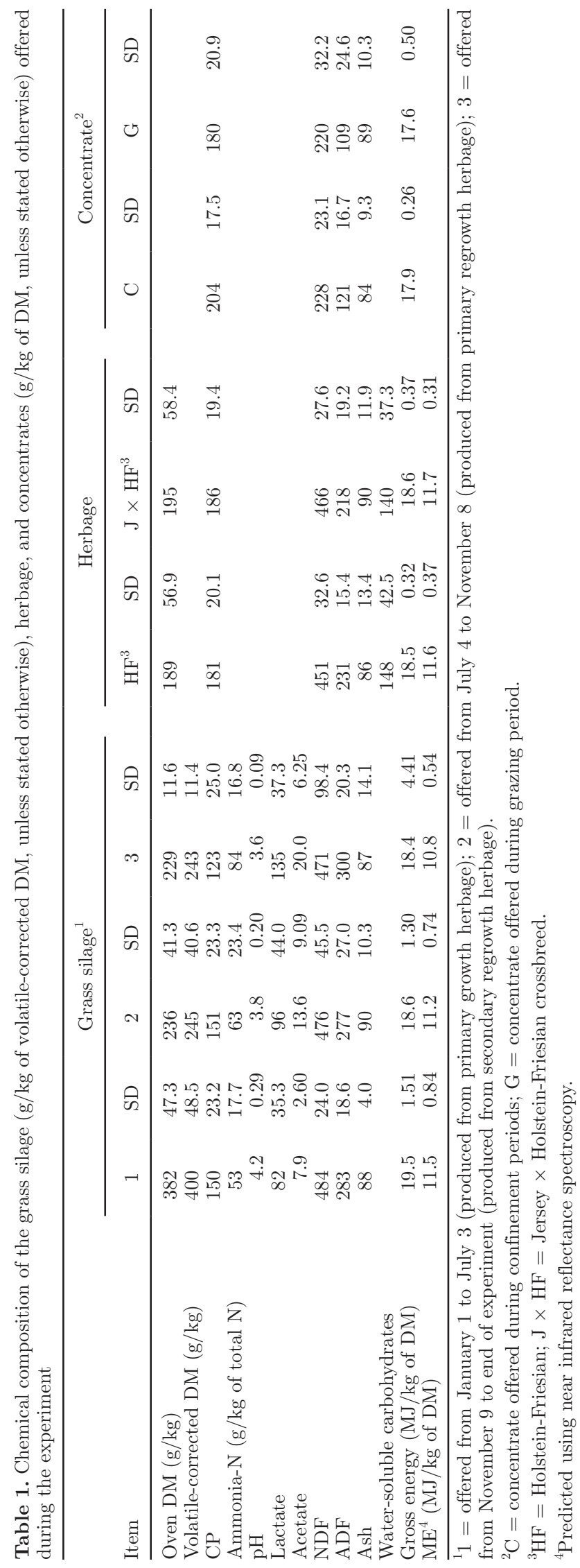


Table 2. Effect of dairy cow genotype ${ }^{1}$ and management system ${ }^{2}$ on food intake (kg of DM/cow per day, unless stated otherwise) throughout the lactation

\begin{tabular}{|c|c|c|c|c|c|c|}
\hline \multirow[b]{2}{*}{ Item } & \multicolumn{2}{|c|}{$\mathrm{CON}$} & \multicolumn{2}{|c|}{ GRZ } & \multirow[b]{2}{*}{ SEM } & \multirow[b]{2}{*}{$P$-value } \\
\hline & $\mathrm{HF}$ & $\mathrm{J} \times \mathrm{HF}$ & $\mathrm{HF}$ & $\mathrm{J} \times \mathrm{HF}$ & & \\
\hline \multicolumn{7}{|c|}{ Calving to $\mathrm{d} 100$} \\
\hline Grass silage & 7.8 & 7.5 & & & 0.27 & NS \\
\hline Concentrate & 11.7 & 11.3 & & & 0.37 & NS \\
\hline Total & 19.0 & 18.8 & & & 0.66 & NS \\
\hline \multicolumn{7}{|l|}{ Day 101 to 200} \\
\hline Grass silage & 9.6 & 9.2 & & & 0.27 & NS \\
\hline Concentrate & 11.4 & 11.0 & & & 0.30 & NS \\
\hline Total & 20.5 & 20.1 & & & 0.59 & NS \\
\hline \multicolumn{7}{|c|}{ Day 201 to end of lactation } \\
\hline Grass silage & 10.1 & 10.8 & & & 0.66 & NS \\
\hline Concentrate & 5.8 & 5.9 & & & 0.68 & NS \\
\hline Total & 16.8 & 16.3 & & & 1.14 & NS \\
\hline \multicolumn{7}{|c|}{ Calving to start of turnout $(31 \mathrm{~d})$} \\
\hline Grass silage & & & 10.5 & 10.4 & 0.41 & NS \\
\hline Concentrate & & & 4.3 & 4.2 & 0.18 & NS \\
\hline Total & & & 15.7 & 15.5 & 0.58 & NS \\
\hline \multicolumn{7}{|c|}{ Start of turnout to full-time grazing $(24 \mathrm{~d})$} \\
\hline Grass silage & & & 6.3 & 6.0 & 0.31 & NS \\
\hline Grass $^{3}$ & & & 7.4 & 7.5 & & \\
\hline Concentrate & & & 5.2 & 5.0 & & \\
\hline Total & & & 18.9 & 18.4 & & \\
\hline \multicolumn{7}{|c|}{ Full-time grazing (199 d) } \\
\hline Grass $^{3}$ & & & 14.8 & 15.1 & & \\
\hline Concentrate & & & 1.3 & 1.3 & & \\
\hline Total & & & 16.1 & 16.4 & & \\
\hline \multicolumn{7}{|c|}{ Full-time housing to end of lactation (38 d) } \\
\hline Grass silage & & & 11.9 & 10.9 & 0.60 & NS \\
\hline Concentrate & & & 3.6 & 3.4 & 0.15 & NS \\
\hline Total & & & 16.5 & 15.1 & 0.73 & NS \\
\hline \multicolumn{7}{|c|}{ Total DMI during lactation (corrected to $305 \mathrm{~d}$ for all treatments) } \\
\hline Grass silage & 2,852 & 2,709 & 997 & 1,069 & & \\
\hline Grass $^{3}$ & 0 & 0 & 2,856 & 2,914 & & \\
\hline Concentrate & 2,961 & 2,850 & 815 & 767 & & \\
\hline Total & 5,813 & 5,559 & 4,668 & 4,750 & & \\
\hline \multicolumn{7}{|c|}{${ }^{1} \mathrm{HF}=$ Holstein-Friesian; $\mathrm{J} \times \mathrm{HF}=$ Jersey $\times$ Holstein-Friesian crossbreed. } \\
\hline \multicolumn{7}{|c|}{${ }^{2} \mathrm{CON}=$ confinement; GRZ = medium-input grazing. } \\
\hline \multicolumn{7}{|c|}{${ }^{3}$ Derived from pre- and postgrazing sward heights. } \\
\hline
\end{tabular}


Table 3. Effect of dairy cow genotype ${ }^{1}$ and management system ${ }^{2}$ on full lactation milk production performance (milk yield, milk composition, milk solids yield, and SCM data adjusted to common DIM for all treatments, namely $305 \mathrm{~d}$ ), milk SCC, mastitis incidence, and milk fatty acid content ( $\mathrm{g} / \mathrm{kg}$ of total fatty acids identified; mean of the 3 measurement periods)

\begin{tabular}{|c|c|c|c|c|c|c|c|c|}
\hline \multirow[b]{2}{*}{ Item } & \multicolumn{2}{|c|}{$\mathrm{CON}$} & \multicolumn{2}{|c|}{ GRZ } & \multirow[b]{2}{*}{ SEM } & \multicolumn{3}{|c|}{ Significance } \\
\hline & $\mathrm{HF}$ & $\mathrm{J} \times \mathrm{HF}$ & $\mathrm{HF}$ & $\mathrm{J} \times \mathrm{HF}$ & & $\begin{array}{c}\text { Genotype } \\
(\mathrm{G})\end{array}$ & $\begin{array}{l}\text { System } \\
(\mathrm{S})\end{array}$ & $\mathrm{G} \times \mathrm{S}$ \\
\hline Milk yield (kg/lactation) & 9,053 & 7,438 & 6,274 & 5,964 & 289.6 & $* *$ & $* * *$ & $*$ \\
\hline \multicolumn{9}{|l|}{ Milk composition $(\mathrm{g} / \mathrm{kg})$} \\
\hline Fat & 43.4 & 48.3 & 43.5 & 46.8 & 0.82 & $* * *$ & NS & NS \\
\hline Protein & 34.0 & 36.8 & 33.6 & 36.0 & 0.57 & $* * *$ & NS & NS \\
\hline Lactose & 46.0 & 46.1 & 44.8 & 45.4 & 0.26 & NS & $* * *$ & NS \\
\hline \multicolumn{9}{|l|}{ Milk solids yield (kg/lactation) } \\
\hline Fat & 390 & 359 & 273 & 279 & 13.2 & NS & $* * *$ & NS \\
\hline Protein & 307 & 273 & 210 & 214 & 9.66 & NS & $* * *$ & NS \\
\hline Lactose & 416 & 343 & 281 & 271 & 12.8 & $* *$ & $* * *$ & $*$ \\
\hline Fat plus protein & 697 & 631 & 483 & 493 & 22.3 & NS & $* * *$ & NS \\
\hline SCM yield $^{3}$ (kg/lactation) & 9,277 & 8,235 & 6,393 & 6,436 & 288.7 & NS & $* * *$ & NS \\
\hline $\mathrm{SCC}(\times 1,000 / \mathrm{mL})$ & 217 & 289 & 79 & 183 & & & & \\
\hline SCS $\left(\log _{10}\right)$ & 2.00 & 2.24 & 1.86 & 2.10 & 0.118 & $* *$ & NS & NS \\
\hline Proportion of cows with one or more cases of mastitis & 0.32 & 0.60 & 0.28 & 0.22 & 0.054 & NS & NS & NS \\
\hline C4 to C14 & 300.1 & 304.0 & 281.2 & 284.9 & 1.05 & NS & $*$ & NS \\
\hline $\mathrm{C} 14: 1$ & 16.9 & 14.3 & 14.9 & 13.9 & 1.10 & $*$ & NS & NS \\
\hline $\mathrm{C} 15: 0$ & 12.6 & 12.4 & 12.9 & 12.0 & 0.04 & NS & NS & NS \\
\hline C15:1 & 2.7 & 2.7 & 3.2 & 2.8 & 0.01 & * & $* * *$ & $* *$ \\
\hline C16:0 & 361.1 & 351.0 & 270.1 & 286.2 & 1.04 & NS & $* * *$ & NS \\
\hline $\mathrm{C} 16: 1$ & 23.0 & 17.8 & 20.7 & 18.4 & 0.13 & $* * *$ & NS & NS \\
\hline $\mathrm{C} 17: 0$ & 5.5 & 5.8 & 5.6 & 5.4 & 0.02 & NS & NS & NS \\
\hline C18:0 & 71.3 & 86.3 & 90.2 & 97.8 & 0.39 & $* * *$ & $* * *$ & NS \\
\hline C18:1 & 178.2 & 173.2 & 259.0 & 242.1 & 0.71 & $*$ & $* * *$ & NS \\
\hline $\mathrm{C} 18: 2$ & 18.3 & 18.5 & 12.8 & 11.5 & 0.07 & NS & $* * *$ & NS \\
\hline $\mathrm{C} 18: 3$ & 6.4 & 6.6 & 8.6 & 8.8 & 0.04 & NS & $* * *$ & NS \\
\hline $\mathrm{C} 20: 0$ & 0.07 & 0.11 & 0.04 & 0.01 & 0.027 & NS & $* *$ & NS \\
\hline Conjugated linoleic acid & 6.1 & 5.4 & 19.0 & 15.4 & 0.11 & $* *$ & $* * *$ & NS \\
\hline
\end{tabular}

${ }^{1} \mathrm{HF}=$ Holstein-Friesian; $\mathrm{J} \times \mathrm{HF}=$ Jersey $\times$ Holstein-Friesian crossbreed

${ }^{2} \mathrm{CON}=$ confinement; GRZ $=$ medium-input grazing.

${ }^{3} \mathrm{SCM}$ yield $(\mathrm{kg})=0.0123$ fat $+0.00656 \mathrm{SNF}-0.0752 \times$ milk yield (where fat and SNF are expressed in $\mathrm{g} / \mathrm{kg}$ and milk yield is expressed in kg; Tyrrell and Reid, 1965). $* P<0.05 ;{ }^{* *} P<0.01 ; * * * P<0.001$. 
on systems CON and GRZ are presented in Table 4, with the actual curves plotted in Figures 1a and 1b, respectively. Across genotypes and systems, the milk yield and fat plus protein yield curves had median $\mathrm{R}^{2}$ values of 0.90 and 0.82 , respectively. Genotype had a significant effect on the $a(P<0.001)$ and $c(P<$ $0.01)$ parameters for daily milk yield and the $b(P<$ $0.05)$ parameter for daily fat plus protein yield, whereas system had a significant effect on each of the $a, b$, and $c$ parameters for both daily milk yield and daily fat plus protein yield $(P<0.001)$. Days to peak milk yield did not differ between the genotypes, whereas days to peak fat plus protein yield was delayed with the crossbred cows $(P<0.01)$. Peak milk yield was highest with the HF cows $(P<0.01)$, whereas peak fat plus protein yield was unaffected by genotype. Peak milk yield and peak fat plus protein yield occurred earlier with GRZ than with $\mathrm{CON}$, whereas cows on $\mathrm{CON}$ had a higher peak milk yield and peak fat plus protein yield than those on GRZ $(P<0.001)$. A significant genotype $\times$ system interaction was found for peak milk yield and peak fat plus protein yield $(P<0.05)$, with HF cows having a peak yield that was 7.6 (milk) and 0.45 (fat plus protein) $\mathrm{kg}$ higher than for the $\mathrm{J} \times \mathrm{HF}$ cows on CON. In contrast to GRZ, peak milk yield was $1.2 \mathrm{~kg}$ higher with the HF cows and peak fat plus protein 0.19 $\mathrm{kg}$ higher with the crossbred cows.

\section{Tissue Changes, Blood Metabolites, and Reproductive Performance}

Throughout the lactation, HF cows were on average $37 \mathrm{~kg}$ heavier than $\mathrm{J} \times \mathrm{HF}$ cows $(P<0.05)$, whereas the latter had a higher mean BCS $(P<0.05$; Table 5$)$. The HF cows experienced a greater BW loss to nadir than the crossbred cows $(P<0.01)$, whereas days to nadir BW was unaffected by genotype. Cows on GRZ had a greater BW loss to nadir and took longer to reach nadir BW than cows on CON.

The effects of genotype and management system on cow BW and BCS during the first 40 wk of lactation are presented in Figures $2 \mathrm{a}$ and $2 \mathrm{~b}$, respectively. Based on repeated-measures analysis, BW differed with genotype, system, and time $(P<0.001)$, and BCS also differed with genotype $(P<0.01)$, system, and time $(P$ $<0.001)$. Although no significant genotype $\times$ system or genotype $\times$ time interactions were observed for $\mathrm{BW}$, we did observe a significant genotype $\times$ system $(P<0.05)$ and genotype $\times$ time $(P<0.001)$ interaction for BCS.

Plasma NEFA and glucose concentrations (Figures $3 \mathrm{a}$ and $3 \mathrm{~b}$, respectively) changed with time postcalving ( $\mathrm{P}$ $<0.001$ ). Although genotype had no significant effect on either plasma NEFA or glucose concentrations, cows on CON had a higher plasma glucose concentration (P

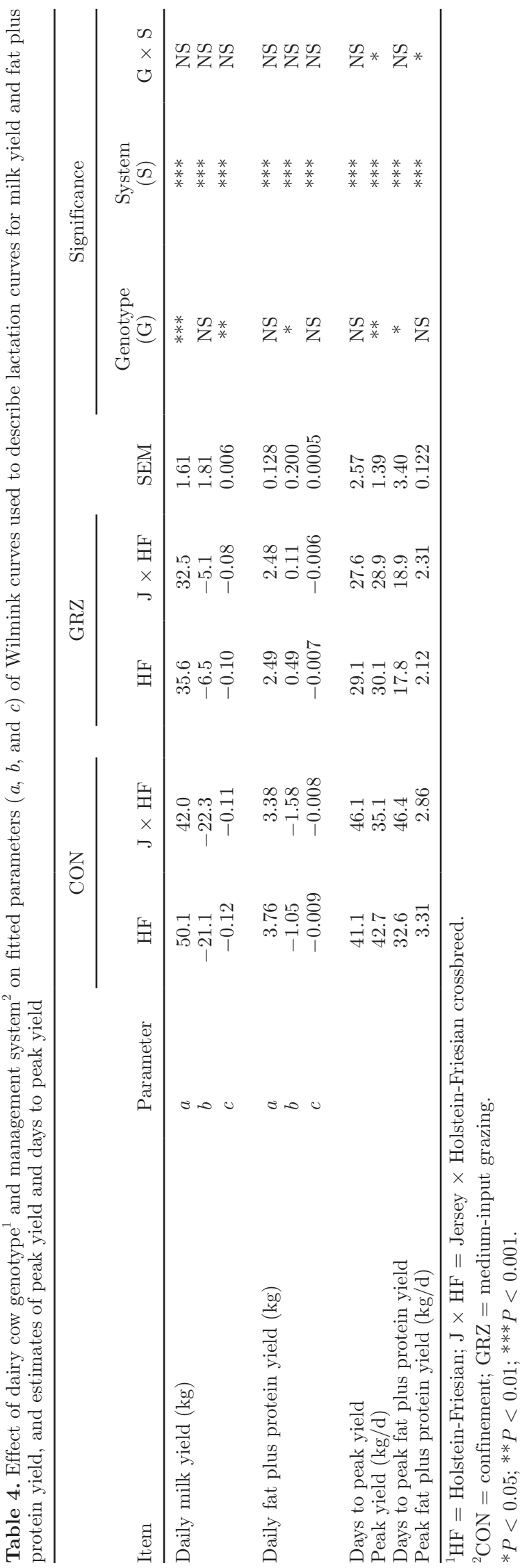

Journal of Dairy Science Vol. 95 No. 3, 2012 
(a)

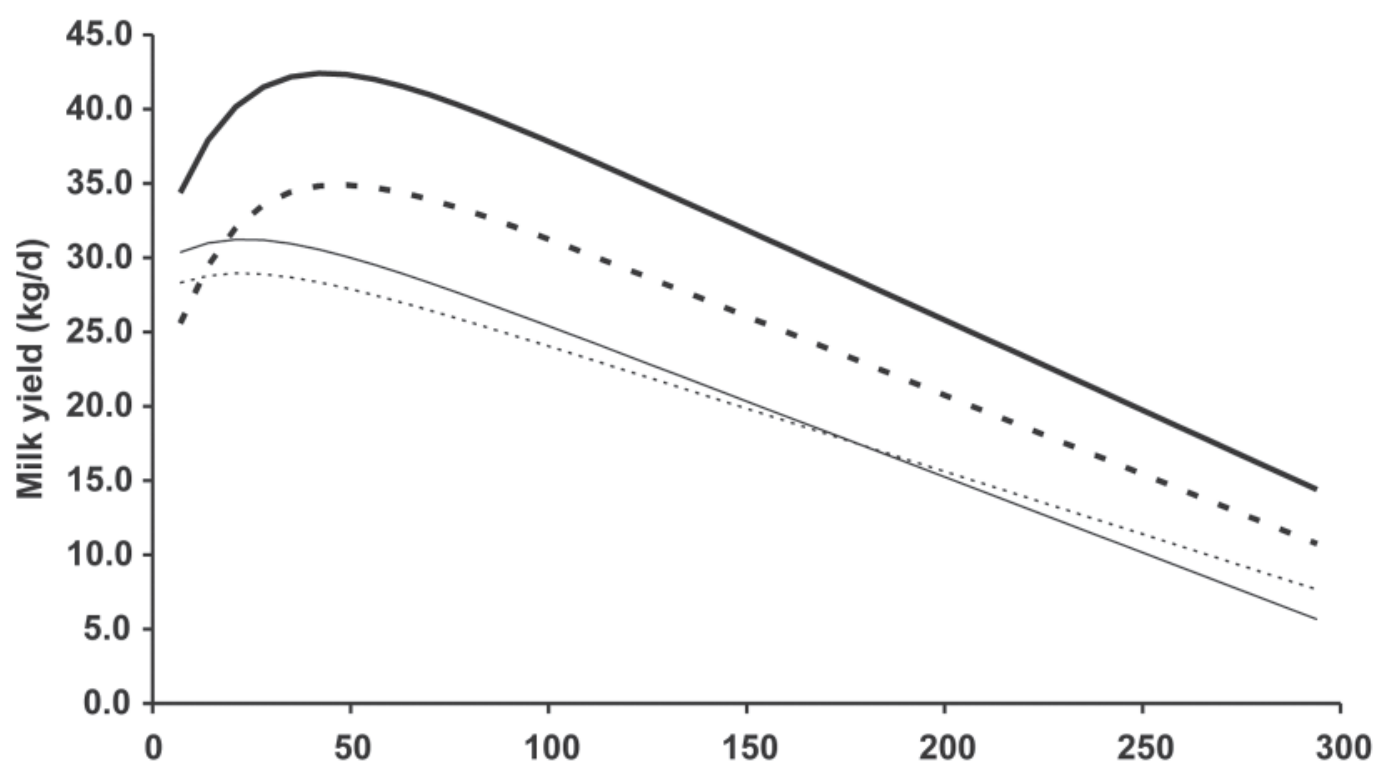

(b)

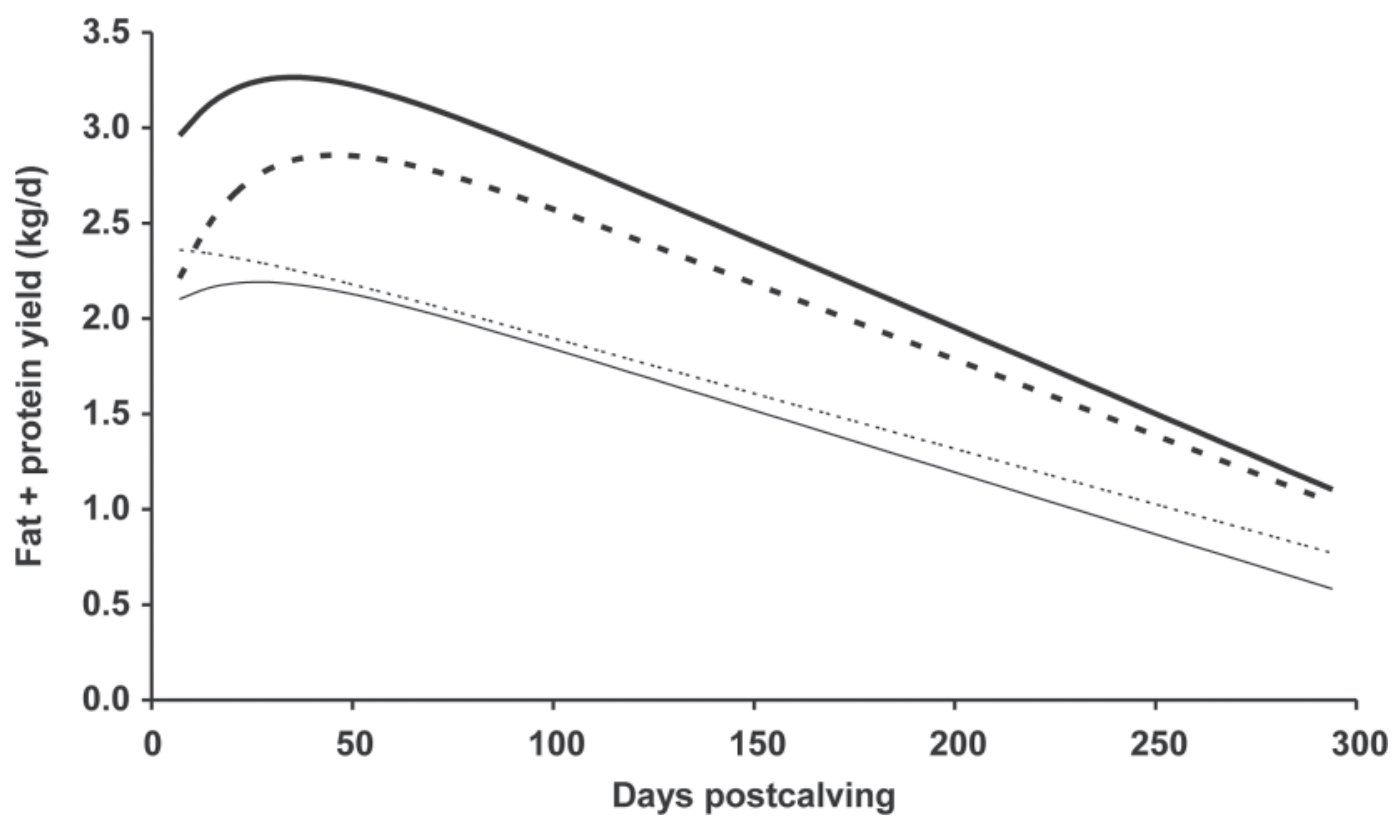

Figure 1. Effect of dairy cow genotype and management system on the lactation profile for (a) milk yield, and (b) fat plus protein yield, as predicted using the Wilmink curve. Heavy solid line = Holstein-Friesian (HF) on confinement (CON); light solid line = HF on grazing (GRZ); heavy dashed line $=$ Jersey $\times$ HF crossbreed $(\mathrm{J} \times \mathrm{HF})$ on $\mathrm{CON}$; light dashed line $=\mathrm{J} \times \mathrm{HF}$ on GRZ

$<0.001)$ than cows on GRZ (3.1 and $3.0 \mathrm{mmol} / \mathrm{L}$, respectively) with the reverse observed for plasma NEFA concentration $(0.21$ and $0.26 \mathrm{mEq} / \mathrm{L}$, respectively; $P<$ $0.01)$. No significant genotype $\times$ system or genotype $\times$ time interactions were observed for any of the blood metabolites examined.

Genotype had no effect on either the proportion of cows showing luteal activity before d 42 or the inter- val to commencement of luteal activity for these cows (Table 5). Although days to first observed heat (HF, 37.5 and $\mathrm{J} \times \mathrm{HF}, 30.0$ ) was significantly lower with the crossbred cows $(P<0.05)$, genotype had no effect on any of the other fertility performance parameters examined. System of milk production did not affect any of the fertility parameters examined within the study, and no significant genotype $\times$ system interac- 
tions were observed for any of the fertility parameters examined.

\section{DISCUSSION}

\section{Food Intakes}

This study was successful in establishing 2 very different nutritional regimens. For example, with CON, grass silage and concentrates comprised 49 and 51\% of total diet DM during the lactation period, respectively, whereas with GRZ, the lactation diet was predominantly grazed grass $(61 \%)$, with grass silage and concentrates comprising 22 and $17 \%$ of the total diet DM, respectively. Nevertheless, the design of the study (in terms of different nutritional strategies adopted within each of CON and GRZ) precludes a comparison of intakes according to the $2 \times 2$ factorial design of the experiment. Furthermore, with system GRZ, grass intakes were estimated on a group basis and, as such, a statistical analysis of grass intake data, or total intake data that included a grass intake component, was not possible.

The results of the current study demonstrated that $\mathrm{J} \times \mathrm{HF}$ crossbred cows managed on confinement diets containing a high concentrate proportion were able to consume similar quantities of DM as HF cows. Similarly, intakes of these 2 cow genotypes did not differ when offered confinement diets containing a lower concentrate proportion (system GRZ) during the pre-turnout and post-rehousing periods. Although relatively few studies have compared intakes of Holstein and Jersey $\times$ Holstein cows on confinement diets, Heins et al. (2008a) found that intakes did not differ between these 2 genotypes during the first 21 wk of lactation, whereas Xue et al. (2011) recorded higher intakes with Jersey $\times$ Holstein cows compared with pure Holstein cows in a short-term study involving primiparous cows.

Although intakes of the 2 genotypes during the grazing period cannot be compared statistically, they were numerically similar (16.1 and $16.3 \mathrm{~kg}$ of $\mathrm{DM} / \mathrm{d}$ for the $\mathrm{HF}$ and $\mathrm{J} \times \mathrm{HF}$ cows, respectively), in agreement with observations during the confinement periods. In addition, herbage intakes within the current study were similar to those reported recently by Prendiville et al. (2009) for Holstein-Friesian and Jersey $\times$ HolsteinFriesian cows, namely 16.9 and $16.2 \mathrm{~kg}$ of DM/cow per day, respectively. In the latter study, the Jersey $\times$ Holstein-Friesian cows had a higher intake/100 kg of BW than the Holstein cows (3.63 and $3.39 \mathrm{~kg}$ of DM, respectively), with Gonzalez-Verdugo et al. (2005) observing a similar trend. These higher intakes per unit of BW may be attributed to several factors, including differences in grazing behavior between genotypes. 


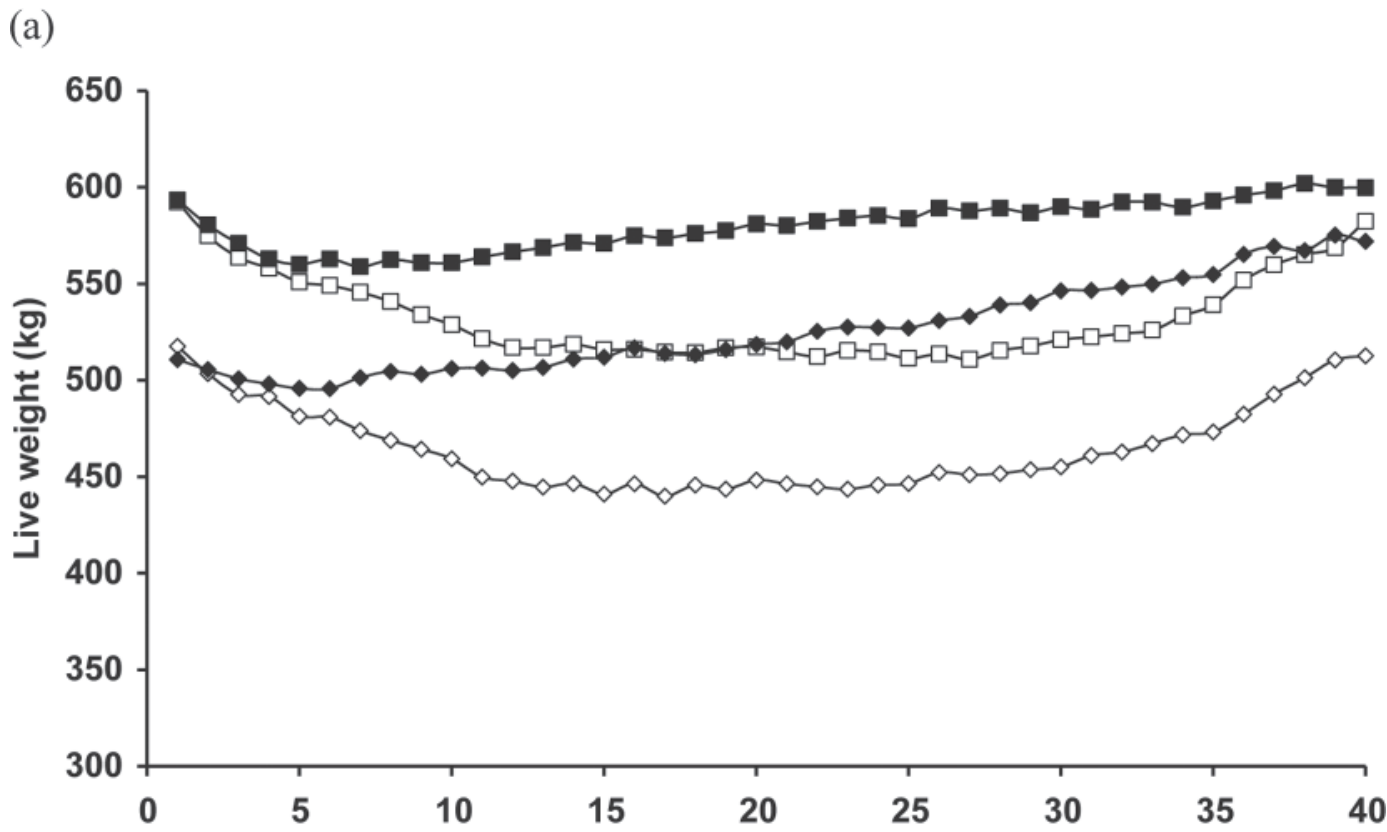

(b)

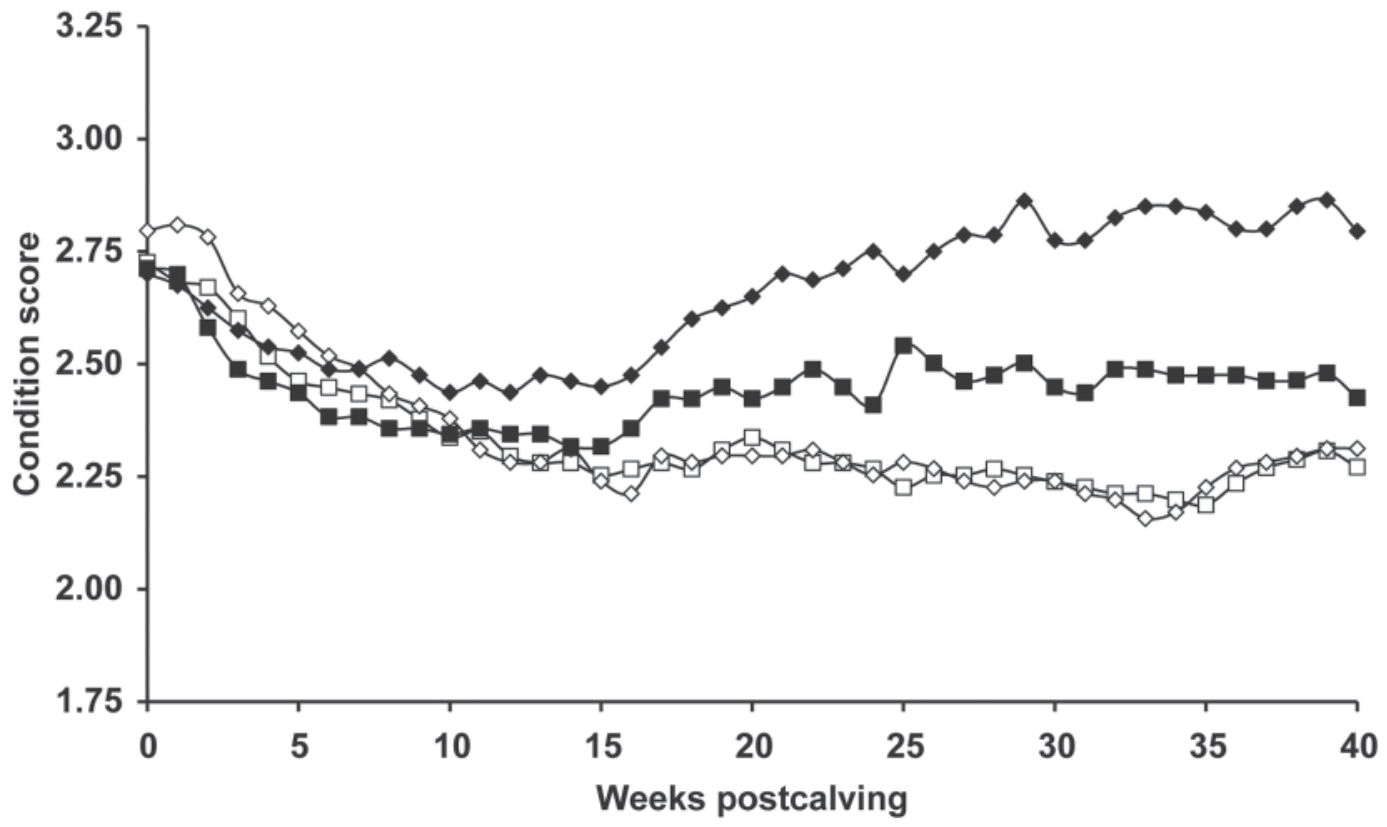

Figure 2. Effect of dairy cow genotype and management system on (a) BW and (b) BCS during the first 40 wk of lactation. $\mathbf{\square}=$ HolsteinFriesian (HF) on confinement $(\mathrm{CON}) ; \square=\mathrm{HF}$ on grazing (GRZ); $=$ Jersey $\times \mathrm{HF}$ crossbreed $(\mathrm{J} \times \mathrm{HF})$ on $\mathrm{CON} ; \diamond=\mathrm{J} \times \mathrm{HF}$ on GRZ.

This was highlighted by Prendiville et al. (2010a) in a comparison of Holstein, Jersey, and Jersey $\times$ Holstein crossbred cows, in which the crossbred cows were observed to have an increased biting rate, increased grass intake per minute, and an associated reduction in grazing bout duration, compared with the parent breed means, with these benefits attributed in part to hybrid vigor. In a similar study, Vance et al. (2010) reported that herbage intakes of Jersey $\times$ Holstein-Friesian cows were similar to those of Holstein-Friesian cows, despite the latter being $75 \mathrm{~kg}$ heavier on average. However, in this study, the smaller crossbred cows had a similar number of bites per minute and tended to have a lower intake per bite than the Holstein cows, while grazing for longer each day and having a greater number of grazing bites per day. This again highlights the ability of smaller crossbred cows to meet their increased nutrient requirements. 
(a)

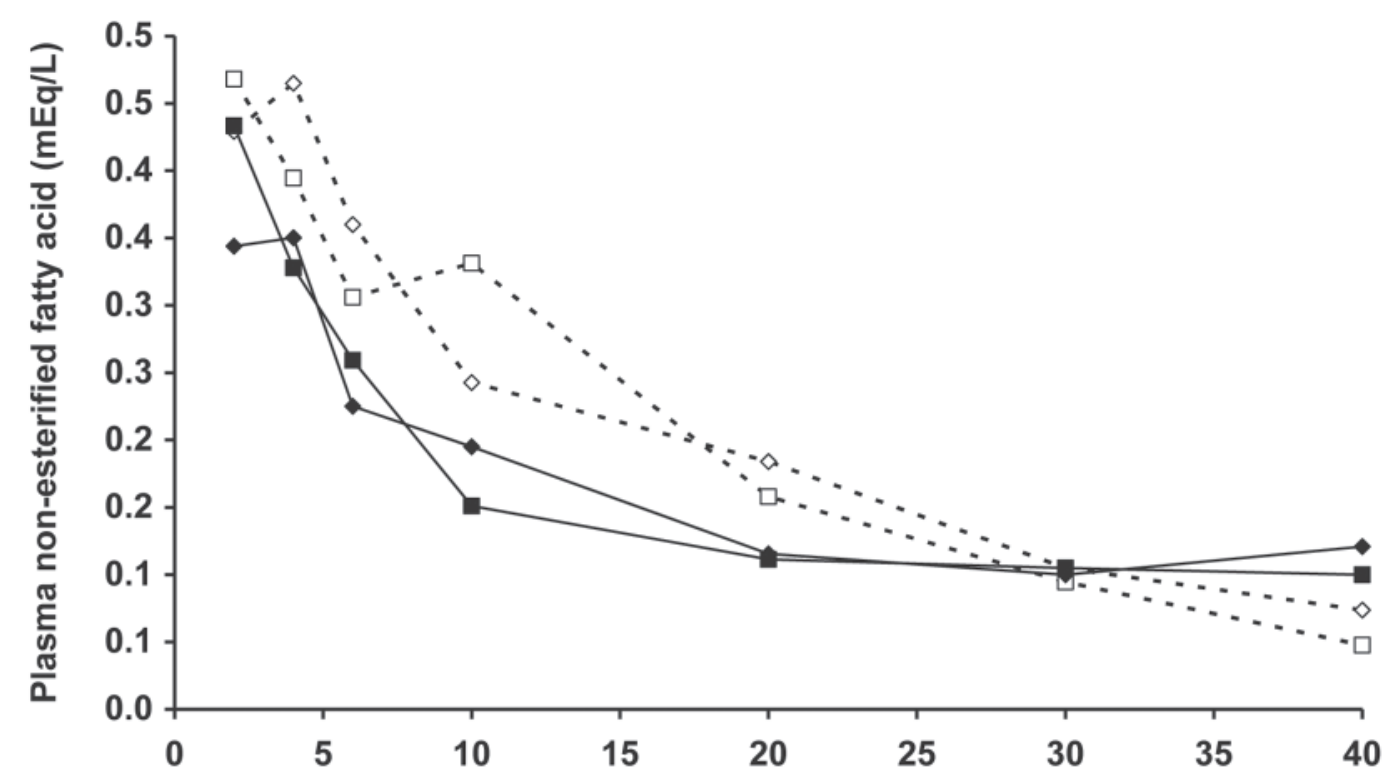

(b)

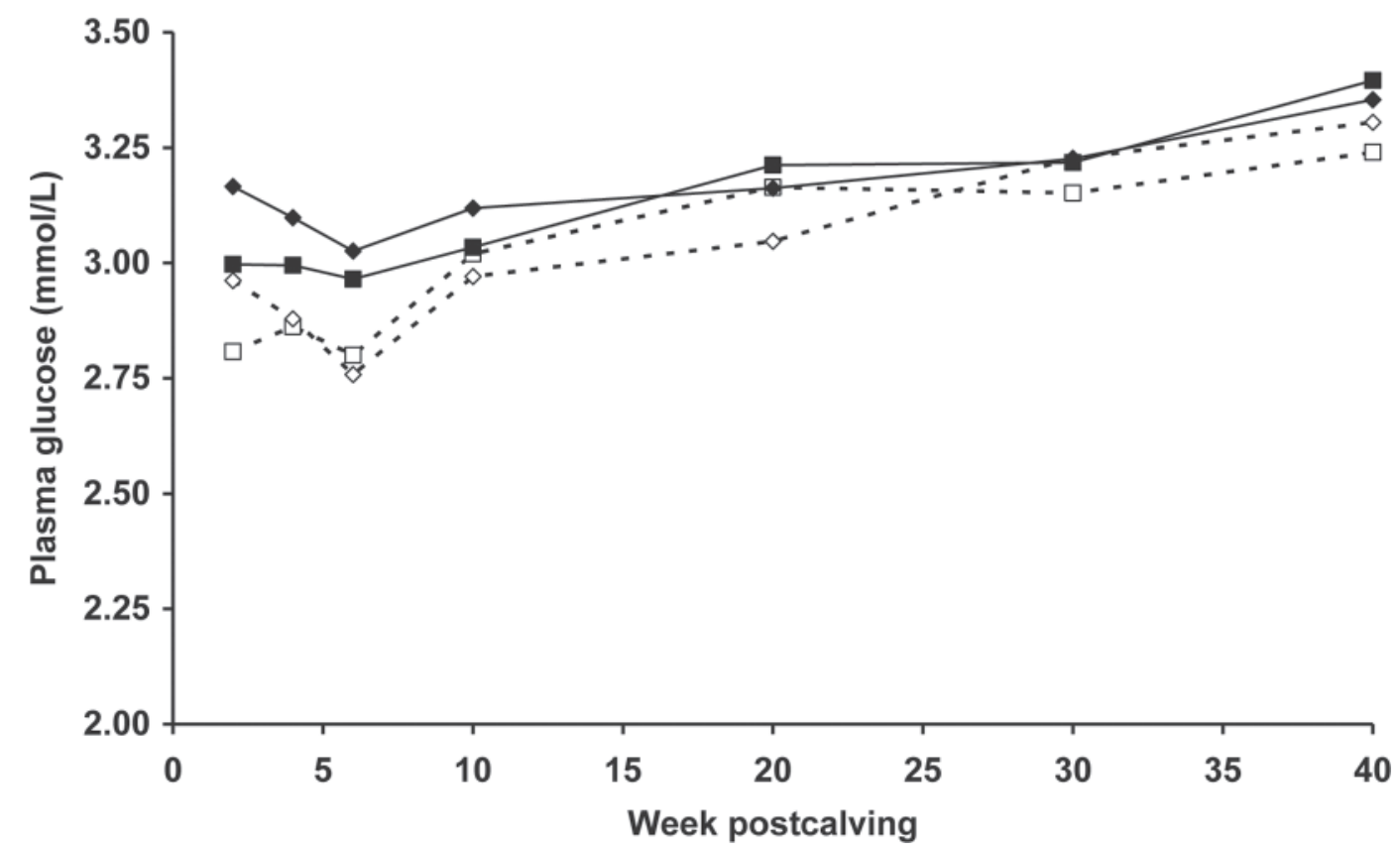

Figure 3. Effect of dairy cow genotype and management system on plasma (a) NEFA and (b) glucose concentrations. $\mathbf{\square}=$ Holstein-Friesian $(\mathrm{HF})$ on confinement $(\mathrm{CON}) ; \square=\mathrm{HF}$ on grazing $(\mathrm{GRZ}) ;-=$ Jersey $\times \mathrm{HF}$ crossbreed $(\mathrm{J} \times \mathrm{HF})$ on $\mathrm{CON} ; \diamond=\mathrm{J} \times \mathrm{HF}$ on GRZ.

Although not analyzed statistically within the current study, total daily DMI across the lactation was approximately $21 \%$ higher with CON than with GRZ. In 2 similar comparisons, intakes of cows managed on confinement diets were $23 \%$ (Kolver and Muller, 1998) and $24 \%$ (Bargo et al., 2002) higher than for cows managed on grazing diets. These results clearly indicate the po- tential to achieve higher total DMI with well-managed confinement diets containing higher concentrate levels.

\section{Milk Production and Composition}

Cows of each genotype on each of systems CON and GRZ had a different mean DIM, primarily a conse- 
quence of differences in calving interval. The use of full-lactation DIM as a covariate within the statistical analysis allows milk production data to be expressed on a common lactation length basis, namely $305 \mathrm{~d}$ (the mean number of days for all cows on the study). In agreement with the findings of previous studies (Prendiville et al., 2009; Vance, 2011), J × HF cows produced milk with a higher fat and protein content than $\mathrm{HF}$ cows, a reflection of the higher milk composition normally associated with the Jersey breed (Rastani et al., 2001; White et al., 2001; Aikman et al., 2008). Across systems, the higher lactation milk yield of the HF cows was reflected in a higher peak yield and a subsequent higher rate of decline in daily milk, the latter reflecting a less persistent lactation profile.

The similar fat plus protein yield of the $\mathrm{HF}$ and $\mathrm{J} \times$ HF cows on system GRZ is in agreement with the findings of many previous studies involving similar nutritional regimens (Auldist et al., 2007; Prendiville et al., 2009). These similar levels of performance are reflected in the similar characteristics (in terms of peak yield and days to peak yield) of the milk yield and fat plus protein yield lactation curves. Thus, this experiment provides clear evidence that $\mathrm{J} \times \mathrm{HF}$ cows can compete favorably with HF cows in terms of milk and milk solids production within low- or medium-input grass-based milk production systems.

With system CON, HF cows produced an additional $1,615 \mathrm{~kg}$ of milk and $1,042 \mathrm{~kg}$ of SCM than the crossbred cows, thus providing clear evidence of a genotype $\times$ environment interaction for milk yield, and strong evidence of a trend for a genotype $\times$ environment interaction with SCM. These interactions reflect the similar interactions that were observed for peak milk yield and peak fat plus protein yield. Evidence of a genotype $x$ system interaction for milk yield and milk constituent yield has been recorded in previous studies involving different dairy cow breeds (Holstein-Friesian and Norwegian Red dairy cows; Keady and Mayne, 2002) and different Holstein-Friesian strains (Horan et al., 2005), with these experiments involving confinement and grazing studies, respectively. Similarly, a genotype $x$ environment interaction for milk yield and milk solids yield was observed in a comparison of overseas HolsteinFriesian cows and New Zealand Holstein-Friesian cows managed within a total confinement or grazing environment (Kolver et al., 2002). In contrast, previous studies involving comparisons of purebred and crossbred cows have provided no evidence of an interaction for milk production parameters (Walsh et al., 2008), although differences in concentrate inputs were relatively small in this latter study. In contrast to the findings of the current study, Heins et al. (2008a) found that Holstein cows and Jersey crossbred cows were able to exhibit a similar fat plus protein yield response to high levels of concentrate supplementation, with this perhaps a reflection of the specific Jersey sires used in the latter study (presumably of North American origin). Indeed, studies involving other crosses have highlighted a similar ability of crossbred cows to respond to high levels of concentrate feeding, with Heins et al. (2006) recording lactation milk yields of 9,757, 8,530, 9,281, and 9,161 $\mathrm{kg} / \mathrm{cow}$ for Holstein, Normande $\times$ Holstein, Scandinavian Red $\times$ Holstein, and Montbeliarde $\times$ Holstein cows, respectively. Although milk yields of each of the crosses were lower than for the Holstein cows, differences were relatively small, especially for the latter 2 genotypes, whereas fat plus protein yields did not actually differ between the Holstein and Holstein $\times$ Scandinavian Red cows. Thus, from a practical point of view, although the findings of the current experiment suggest that Jersey crossbred cows sired by New Zealand and Danish sires were unable to exhibit milk and SCM yield responses to high concentrate feed levels similar to those of Holstein-Friesian cows, evidence from other studies suggests that levels of production performance similar to that of Holstein cows can be achieved when some other cattle breeds, and indeed other strains of Jersey, are used in crossbreeding programs. Thus, when considering the adoption of crossbreeding within higher concentrate input systems, choice of breed and strain of sire within a breed require careful consideration.

Although milk composition did not differ between systems CON and GRZ, Kolver and Muller (1998) reported significantly higher milk protein concentrations in cows offered a TMR compared with cows offered a grazed grass-based diet, whereas Roberts and Kelly (1990) and Ferris et al. (2007) reported higher milk protein concentrations with cows grazing full-time compared with those housed at night and offered grass silage. Even though grazed grass-based diets normally promote milk protein synthesis compared with grass silage-based diets, total energy intake and energy density of the diet are also drivers of milk protein synthesis (Lock and Shingfield, 2003). Nevertheless, these findings do demonstrate that milk of excellent compositional quality can be produced from diverse production systems.

\section{Milk Fatty Acids}

Dietary intake of n-3 polyunsaturated fatty acids and CLA has been recognized as having potential positive effects on human health (Lock and Bauman, 2004). Although the fatty acid content of milk may be modified through nutritional strategies, a more acceptable approach may be to modify the fatty acid content of milk through breeding. Several studies have examined the 
effect of dairy cow genotype on the fatty acid content of milk, although the results have been conflicting. For example, in a comparison involving Holstein and Jersey crossbred cows, Palladino et al. (2010) observed that the concentration of short-chain milk fatty acids (C4C14) was unaffected by genotype, in agreement with the findings of the current study, whereas White et al. (2001) reported higher concentrations of short-chain fatty acids (C6-C14) in milk produced by purebred Jersey cows compared with Holstein cows. Similarly, in agreement with the findings of the current study, White et al. (2001) observed concentrations of C16:0 saturated fat to be unaffected by genotype, whereas Palladino et al. (2010) reported significantly higher concentrations of C16:0 fat in milk produced by purebred Jersey and Jersey $\times$ Holstein-Friesian cows compared with milk produced by purebred Holstein cows.

Although the majority of saturated fats are considered to have harmful effects on human health, C18:0 is known to have a neutralizing effect on blood cholesterol levels. Within the current study, concentrations of C18:0 were highest with $\mathrm{J} \times \mathrm{HF}$ cows, although no such effect was observed by Palladino et al. (2010). The higher milk CLA concentration with the HF compared with the $\mathrm{J} \times \mathrm{HF}$ cows in the current study may be due to the HF cows having a higher stearoyl-CoA desaturase activity (Palladino et al., 2010), the conversion of vaccenic acid (trans-11 C18:1) to CLA via stearoylCoA desaturase activity being a major source of CLA in milk (Lock and Garnsworthy, 2003). Thus, although some evidence suggests that differences exist among breeds for milk fatty acid concentrations, the findings are by no means consistent between studies, and variations between individual sires within a breed might be of greater importance than the variation between breeds per se.

Differences in the fatty acid content of milk between systems GRZ and CON are in broad agreement with the findings of similar studies in which grazed grass was replaced by concentrates or conserved forage (White et al., 2001; Schroeder et al., 2003; Ferris et al., 2007). In general, concentrations of saturated fatty acids decrease, whereas concentrations of unsaturated fatty acids (especially C18:1, C18:3, and CLA) increase with increasing proportions of grazed grass in the diet. Although the beneficial effects of offering diets containing a high proportion of pasture on the CLA content of milk is now well established (Dhiman et al., 1999; White et al., 2001; Dewhurst et al., 2006), the increase in the CLA content of milk between systems CON and GRZ within the current study $(67 \%)$ was particularly dramatic. Pasture-based diets are known to be the best substrate for the synthesis of CLA, a consequence of the higher accumulation of vaccenic acid following extensive rumen hydrogenation of both linoleic and linolenic fatty acids (Dewhurst et al., 2006).

\section{Udder Health}

Although the majority of studies involving comparisons of Holstein-Friesian and Jersey $\times$ Holstein-Friesian cows have reported no difference between genotypes for mean SCS (Heins et al., 2008b; Prendiville et al., 2010b), the $\mathrm{J} \times \mathrm{HF}$ cows had a higher SCS than the HF cows within the current study. This is perhaps not entirely unexpected as Jersey cows have been observed to have higher SCC than Holstein cows in some (Sewalem et al., 2006) but not all (Washburn et al., 2002: Prendiville et al., 2010b) comparisons of these 2 breeds. In addition, hybrid vigor for udder health traits is limited (Walsh et al., 2007; Begley et al., 2009; Prendiville et al., 2010b), with unfavorable heterosis for mastitis incidence and SCC having been reported by VanRaden and Sanders (2003), with those authors relating this to an increase in milk yield in crossbred cows and an associated increase in udder stress.

Within the current study, a trend was observed suggesting a lower SCS with cows managed on GRZ compared with CON $(P<0.07)$, which may be due to reduced exposure to environmental pathogens with system GRZ. Cows managed within a grazing system have been observed to have a lower incidence of mastitis compared with those managed within a confinement system (Washburn et al., 2002), although other reports have observed no difference between these 2 milk production systems for SCC (Kolver and Muller, 1998; Bargo et al., 2002; Washburn et al., 2002).

\section{Body Tissue Change and Blood Metabolites}

The higher BCS and lower BW of the $\mathrm{J} \times \mathrm{HF}$ cows are in agreement with the findings of Auldist et al. (2007) and Heins et al. (2008a). With system GRZ, both genotypes appeared to lose BW at a similar rate until approximately wk 15 of lactation, experience little change in BW during the next 15 wk, and thereafter gain BW until drying-off. These trends were similar to those observed by Vance (2011) when these same 2 genotypes were managed on a similar low-input grassbased system during 3 successive years. In addition, changes in BCS within the current study were also similar to those reported by Vance (2011), with both genotypes losing a similar amount of body condition in early lactation, and showing little evidence of BCS gain until approximately wk 35 of lactation. These findings highlight how difficult it can be for high-genetic-merit dairy cows, and indeed crossbred cows bred from highgenetic-merit dairy cows, to gain body condition in late 
lactation on predominantly forage-based diets. Indeed, the gain in $\mathrm{BW}$ during wk 30 to 40 of lactation may well have been primarily a "gut fill" effect due to cows being offered grass silage-based diets after rehousing, with this suggestion supported by the fact that the gain in body condition during this same period was extremely small.

Both the BW and BCS curve trajectories of cows managed on CON were very different from those on GRZ, while evidence was found of a genotype $\times$ environment interaction when weekly BW and BCS data were examined (Figure 2a and 2b). This interaction appears to be largely driven by differences between genotypes within system $\mathrm{CON}$, and although not particularly evident during the first 10 to 15 wk of lactation (during which time $\mathrm{BW}$ loss was greater with the $\mathrm{HF}$ cows), thereafter the $\mathrm{J} \times \mathrm{HF}$ cows on system $\mathrm{CON}$ had a much greater trajectory for BW gain and BCS gain. This difference can be attributed to the $\mathrm{J} \times \mathrm{HF}$ cows partitioning a greater proportion of food nutrients consumed to body tissue reserves compared with the HF cows. Indeed, this was the reason that concentrate inclusion levels with both genotypes were reduced to $25 \%$ (DM basis) from d 250 of lactation onward (as described earlier), the $\mathrm{J} \times \mathrm{HF}$ cows being at a risk of becoming over-fat during late lactation. Although the HF cows lost more BW (and appeared to lose more BCS) than the crossbred cows in early lactation, no evidence was found of differing trends in the concentrations of plasma NEFA and BHBA during early lactation (both considered indicators of tissue mobilization).

These differences in BW and BCS response curves between genotypes and systems provide an explanation for the trend $(P=0.069)$ toward a genotype $\times$ environment interaction for SCM within this study. For example, with system GRZ, similar food intakes and changes in body tissue reserves with both genotypes were reflected in similar outputs of SCM. However, although food intake for the 2 cow genotypes was similar with CON, SCM tended to be lower with the $\mathrm{J} \times \mathrm{HF}$ cows $(1,042 \mathrm{~kg})$, with this reflecting the increased tissue mobilization with the HF cows in early lactation, and the fact that a proportion of the nutrients consumed by the crossbred cows in mid to late lactation was partitioned to body tissue reserves, rather than milk. A similar response has been observed in previous studies, with Yan et al. (2006) reporting that Holstein-Friesian cows managed on a high concentrate diet exhibited a greater milk production response than Norwegian Red cows, with this due to the latter partitioning additional nutrients to body tissue reserves. Similarly, Tyrrell et al. (1990) reported that Holstein-Friesian cows partitioned a greater proportion of their energy consumed into milk than purebred Jersey cows. In view of the very large difference between purebred Holstein and purebred Jersey cows in terms of milk production potential, it is perhaps not unexpected that their crosses would be unable to respond to concentrate supplementation to the same extent as purebred Holstein cows.

The lower BW loss observed in cows managed on CON compared with GRZ (42 and $91 \mathrm{~kg}$, respectively) is in line with previous reports in the literature. For example, Kolver and Muller (1998) and Bargo et al. (2002) reported greater BW and BCS losses in cows managed on a grazing system compared with cows managed within a confinement system. The higher BW and BCS loss with system GRZ compared with system CON is reflected in the higher plasma NEFA concentrations observed in cows within the former system, in agreement with the findings of Bargo et al. (2002).

\section{Fertility}

Although the current experiment did not provide strong evidence of a difference in fertility performance between the $\mathrm{HF}$ and the $\mathrm{J} \times \mathrm{HF}$ cows, days to first observed heat was shorter with the crossbred cows, and a numerical trend was observed for higher conception rates and 12-wk in-calf rate with the $\mathrm{J} \times \mathrm{HF}$ cows. However, when considering the fertility trends within the current study, the relatively small number of cows involved in the study must be recognized, together with the binary nature of much of the data presented. Nevertheless, significant improvements in fertility performance have been observed with Jersey crossbred cows in other studies within the literature (Auldist et al., 2007), including an earlier large-scale study at AFBI (Vance, 2011). In addition, the current study provided no evidence that fertility performance was influenced by management system, which is perhaps surprising in view of the large difference $(2,114 \mathrm{~kg} / \mathrm{cow})$ in concentrate input between systems and the very different trends in tissue mobilization and deposition observed. However, ample evidence exists in the literature that increasing concentrate feed levels has little effect on fertility performance. For example, Horan et al. (2004) reported that an increase in concentrate feed levels from 350 to $1,500 \mathrm{~kg} /$ cow had no effect on overall fertility performance in 3 strains of Holstein-Friesian dairy cows. Furthermore, Washburn et al. (2002) observed no significant difference in the reproductive performance of cows managed on either a confinement or a grazing system.

\section{CONCLUSIONS}

The lighter-weight $\mathrm{J} \times \mathrm{HF}$ cows were able to compete in terms of milk production with the larger HF 
cows within the medium-input grazing system, with the crossbred cows compensating for their smaller size by having a higher intake per kilogram of BW. However, the $\mathrm{J} \times \mathrm{HF}$ cows were unable to exhibit as large a milk production response to high concentrate feed levels as the HF (with a similar trend observed for SCM), the HF cows mobilizing more body tissue in early lactation and partitioning less feed nutrients to body tissue reserves in mid or late lactation. In summary, although well-suited to medium concentrate input grazing systems, $\mathrm{J} \times \mathrm{HF}$ cows would appear less suited than HF cows to high concentrate input systems.

\section{ACKNOWLEDGMENTS}

Thanks are due to the Dairy Unit staff at AFBI Hillsborough for care of the experimental animals and for assisting with experimental measurements. This study was co-funded by the Department of Agriculture and Rural Development (DARD) in Northern Ireland and by AgriSearch (farmer levy). Elaine Vance acknowledges receipt of a DARD postgraduate studentship.

\section{REFERENCES}

Aikman, P. C., C. K. Reynolds, and D. E. Beever. 2008. Diet digestibility, rate of passage, and eating and rumination behaviour of Jersey and Holstein Cows. J. Dairy Sci. 91:1103-1114.

Auldist, M. J., M. F. S. Pyman, C. Grainger, and K. L. Macmillan. 2007. Comparative reproductive performance and early lactation productivity of Jersey $\times$ Holstein cows in predominantly Holstein herds in a pasture-based dairying system. J. Dairy Sci. 90:48564862 .

Bargo, F., L. D. Muller, J. E. Delahoy, and T. W. Cassidy. 2002. Performance of high producing dairy cows with three different feeding systems combining pasture and total mixed rations. J. Dairy Sci. 85:2948-2963.

Begley, N., F. Buckley, K. M. Pierce, A. G. Fahey, and B. A. Mallard. 2009. Differences in udder health and immune response traits of Holstein-Friesians, Norwegian Reds, and their crosses in second lactation. J. Dairy Sci. 92:749-757.

Dewhurst, R. J., K. J. Shingfield, M. R. F. Lee, and N. D. Scollan. 2006. Increasing the concentrations of beneficial polyunsaturated fatty acids in milk produced by dairy cows in high-forage systems. Anim. Feed Sci. Technol. 131:168-206.

Dhiman, T. R., G. R. Anand, L. D. Satter, and M. W. Pariza. 1999. Conjugated linoleic acid content of milk from cows fed different diets. J. Dairy Sci. 82:2146-2156.

Edmonson, A. J., I. J. Lean, L. D. Weaver, T. Farver, and G. Webster. 1989. A body condition scoring chart for Holstein dairy cows. J. Dairy Sci. $72: 68-78$.

Ferris, C. P., R. C. Binnie, J. P. Frost, and D. C. Patterson. 2007. Effect of offering silage during housing at night on the performance of grazing dairy cows and on labour requirements. Grass Forage Sci. 63:138-151.

Ferris, C. P., F. J. Gordon, D. C. Patterson, C. S. Mayne, and D. J. Kilpatrick. 1999. The influence of dairy cow genetic merit on the direct and residual response to level of concentrate supplementation. J. Agric. Sci. 132:467-481.

Gonzalez-Verdugo, H., J. C. Magofke, and C. Mella. 2005. Productivity, consumption and biological efficiency in New Zealand Friesian cows and $\mathrm{F}_{1}$ (New Zealand Jersey-Friesian) calving in late winter in the Xth Region, Chile. Arch. Med. Vet. 37:37-47.
Harris, B. L., C. W. Holmes, A. M. Winkelman, and Z. Z. Xu. 2000. Comparisons between fertility and survival of strains of HolsteinFriesian cows, Jersey cows and their crosses in New Zealand. Pages 491-493 in Fertility in the High-Producing Dairy Cow. Occ. Publ. No 26. Proc. British Society of Animal Science, Galway, Ireland. Br. Soc. Anim. Sci., Edinburgh, UK.

Heins, B. J., L. B. Hansen, and A. J. Seykora. 2006. Production of pure Holsteins versus crossdbreds of Holstein with Normande, Montbeliarde, and Scandinavian Red. J. Dairy Sci. 89:2799-2804.

Heins, B. J., L. B. Hansen, A. J. Seykora, A. R. Hazel, D. G. Johnson, and J. G. Linn. 2008a. Crossbreds of Jersey $\times$ Holstein compared with pure Holsteins for body weight, body condition score, dry matter intake, and feed efficiency during the first one hundred and fifty days of first lactation. J. Dairy Sci. 91:3716-3722.

Heins, B. J., L. B. Hansen, A. J. Seykora, D. G. Johnson, J. G. Linn, J. E. Romano, and A. R. Hazel. 2008b. Crossbreds of Jersey $\times$ Holstein compared with pure Holsteins for production, fertility, and body and udder measurements during first lactation. J. Dairy Sci. 91:1270-1278.

Horan, B., P. Dillon, P. Faverdin, L. Delaby, F. Buckley, and M. Rath. 2005. The interaction of strain of Holstein-Friesian cows and pasture-based feed systems on milk yield, body weight, and body condition score. J. Dairy Sci. 88:1231-1243.

Horan, B., J. F. Mee, M. Rath, P. O'Connor, and P. Dillon. 2004. The effect of strain of Holstein-Friesian cow and feeding system on reproductive performance in seasonal-calving milk production systems. Anim. Sci. 79:453-467.

Keady, T. W. J., and C. S. Mayne. 2002. The effect of two levels of nutrient intake on milk production of two dairy cow genotypes. Page 12 in Proc. Br. Soc. Anim. Sci. Winter Meeting, York, United Kingdom. Br. Soc. Anim. Sci., Edinburgh, UK.

Keady, T. W. J., C. S. Mayne, and D. A. Fitzpatrick. 2000. Effects of supplementation of dairy cattle with fish oil on silage intake, milk yield and milk composition. J. Dairy Res. 67:137-153.

Kolver, E. S., and L. D. Muller. 1998. Performance and nutrient intake of high producing Holstein cows consuming pasture or a total mixed ration. J. Dairy Sci. 81:1403-1411.

Kolver, E. S., J. F. Roche, M. J. De Veth, P. L. Thorne, and A. R. Napper. 2002. Total mixed rations versus pasture diets: Evidence for a genotype $\times$ diet interaction in dairy cow performance. Proc. N.Z. Soc. Anim. Prod. 62:246-251.

Lock, A. L., and D. E. Bauman. 2004. Modifying milk fat composition of dairy cows to enhance fatty acids beneficial to human health. Lipids 39:1197-1206.

Lock, A. L., and P. C. Garnsworthy. 2003. Seasonal variation in milk conjugated linoleic acid and $\Delta^{9}$-desaturase activity in dairy cows. Livest. Prod. Sci. 79:47-59.

Lock, A. L., and K. J. Shingfield. 2003. Optimising milk composition. Pages 107-188 in Dairying-Using Science to Meet Consumer Needs. Proc. Br. Soc. Anim. Sci., Publication 29. Br. Soc. Anim. Sci., Edinburgh, UK.

Mayne, C. S., and F. J. Gordon. 1986. The effect of harvesting system on nutrient losses during silage making. 1. Field losses. Grass Forage Sci. 41:17-25.

Palladino, R. A., F. Buckley, R. Prendiville, J. J. Murphy, J. Callan, and D. A. Kenny. 2010. A comparison between Holstein-Friesian and Jersey dairy cows and their F1 hybrid on milk fatty acid composition under grazing conditions. J. Dairy Sci. 93:2176-2184.

Park, R. S., R. E. Agnew, F. J. Gordon, and R. W. J. Steen. 1998. The use of near infrared reflectance spectroscopy (NIRS) on undried samples of grass silage to predict chemical composition and digestibility parameters. Anim. Feed Sci. Technol. 72:155-167.

Payne, R. W., D. A. Murray, S. A. Harding, D. B. Baird, and D. M. Soutar. 2008. Introduction: GenStat for Windows. 11th ed. VSN International, Hemel Hempstead, UK.

Porter, M. G. 1992. Comparison of sample preparation methods for the determination of the gross energy concentration of fresh silage. Anim. Feed Sci. Technol. 37:201-208.

Prendiville, R., E. Lewis, K. M. Pierce, and F. Buckley. 2010a. Comparative grazing behaviour of lactating Holstein-Friesian, Jersey, and Jersey $\times$ Holstein-Friesian dairy cows and its association with 
intake capacity and production efficiency. J. Dairy Sci. 93:764774 .

Prendiville, R., K. M. Pierce, and F. Buckley. 2009. An evaluation of production efficiencies among lactating Holstein-Friesian, Jersey, and Jersey $\times$ Holstein-Friesian cows at pasture. J. Dairy Sci. 92:6176-6185.

Prendiville, R., K. M. Pierce, and F. Buckley. 2010b. A comparison between Holstein-Friesian and Jersey dairy cows and their F1 cross with regard to milk yield, somatic cell score, mastitis, and milking characteristics under grazing conditions. J. Dairy Sci. 93:2741-2750.

Rastani, R. R., S. M. Andrew, S. A. Zinn, and C. J. Sniffen. 2001. Body composition and estimated tissue energy balance in Jersey and Holstein cows during early lactation. J. Dairy Sci. 84:12011209.

Roberts, D. J., and E. F. Kelly. 1990. Comparison of a straw/concentrate mixture with silage as a buffer feed for grazing dairy cows. Grass Forage Sci. 45:103-106.

Sauer, M. J., J. A. Foulkes, A. Worsfold, and B. A. Morris. 1986. Use of progesterone 11-glucuronide-alkaline phosphatase conjugate in a sensitive microtitre-plate enzyme immunoassay of progesterone in milk and its application to pregnancy testing in dairy cattle. J. Reprod. Fertil. 76:375-391.

Schroeder, G. F., J. E. Delahoy, I. Vidauireta, F. Bargo, G. A. Gagliostro, and L. D. Muller. 2003. Milk fatty acid composition of cows fed a total mixed ration or pasture plus concentrates replacing corn with fat. J. Dairy Sci. 86:3237-3248.

Sewalem, A., F. Miglior, G. J. Kistemaker, and B. J. Van Doormaal. 2006. Analysis of the relationship between somatic cell score and functional longevity in Canadian dairy cattle. J. Dairy Sci. 89:3609-3614.

Tyrrell, H. F., and J. T. Reid. 1965. Prediction of the energy value of cow's milk. J. Dairy Sci. 48:1215-1223.

Tyrrell, H. F., C. K. Reynolds, and H. D. Baxter. 1990. Energy metabolism of Jersey and Holstein cows fed total mixed diets with or without whole cottonseed. J. Dairy Sci. 73(Suppl. 1):250. (Abstr.)
Vance, E. R. 2011. A comparison of the performance and feeding behaviour of Holstein-Friesian dairy cows and Jersey $\times$ HolsteinFriesian crossbred dairy cows, within grassland based milk production systems. PhD Thesis. Queen's University Belfast, UK.

Vance, E. R., C. P. Ferris, C. T. Elliott, and D. J. Kilpatrick. 2010 Food intake and feeding behaviour of Holstein-Friesian and Jersey $\mathrm{x}$ Holstein-Friesian crossbred dairy cows. Page 141 in Proc. Br. Soc. Anim. Sci. Winter Meeting, Queen's University Belfast. Br. Soc. Anim. Sci., Edinburgh, UK.

VanRaden, P. M., and A. H. Sanders. 2003. Economic merit of crossbred and purebred US Dairy Cattle. J. Dairy Sci. 86:1036-1044.

Walsh, S., F. Buckley, D. P. Berry, M. Rath, K. Pierce, N. Byrne, and P. Dillon. 2007. Effects of breed, feeding system, and parity on udder health and milking characteristics. J. Dairy Sci. 90:5767-5779.

Walsh, S., F. Buckley, K. Pierce, N. Byrne, J. Patton, and P. Dillon. 2008. Effects of breed and feeding system on milk production, body weight, body condition score, reproductive performance, and postpartum ovarian function. J. Dairy Sci. 91:4401-4413.

Washburn, S. P. S. L. White, J. T. Green Jr., and G. A. Benson. 2002 Reproduction, mastitis, and body condition of seasonally calved Holstein and Jersey cows in confinement or pasture systems. J. Dairy Sci. 85:105-111.

White, S. L., J. A. Bertrand, M. R. Wade, S. P. Washburn, J. T. Green, and T. C. Jenkins. 2001. Comparison of fatty acid content of milk from Jersey and Holstein cows consuming pasture or a total mixed ration. J. Dairy Sci. 84:2295-2301.

Wilmink, J. B. M. 1987. Adjustment of lactation yield for age at calving in relation to level of production. Livest. Prod. Sci. 16:321334.

Xue, B., T. Yan, C. P. Ferris, and C. S. Mayne. 2011. Milk production and energetic efficiency of Holstein and Jersey-Holstein crossbred dairy cows offered diets containing grass silage. J. Dairy Sci 94:1455-1464.

Yan, T., C. S. Mayne, T. W. J. Keady, and R. E. Agnew. 2006. Effects of dairy cow genotype with two planes of nutrition on energy partitioning between milk and body tissue. J. Dairy Sci. 89:1031-1042. 